\title{
Physicochemical, Proximate and Sensory Properties of Pineapple (Ananas sp.) Syrup Developed from Its Organic Side-Stream
}

\author{
Charles Tortoe $^{1 *}$, Paa-Nii T. Johnson ${ }^{1}$, Ted Slaghek ${ }^{2}$, Matilde Miedema², Theo Timmermans ${ }^{2}$ \\ ${ }^{1}$ CSIR-Food Research Institute, Accra, Ghana; ${ }^{2}$ TNO, Hoofddorp, The Netherlands. \\ Email: "ctortoe@yahoo.co.uk
}

Received October $3^{\text {rd }}, 2012$; revised December $18^{\text {th }}, 2012$; accepted December $25^{\text {th }}, 2012$

\begin{abstract}
A major economical industrial challenge from pineapple (Ananas sp.) processing contributing to environmental pollution is the organic side-streams of pineapple. The physicochemical, proximate and sensory properties of organic sidestream pineapple syrup (OSPS) developed from Smooth cayenne, Sugar loaf and $\mathrm{MD}_{2}$ pineapple varieties were evaluated. Organic side-stream pineapple syrup developed from $\mathrm{MD}_{2}$ recorded the highest moisture content with a corresponding water activity. The colour change in OSPS was significant among the three varieties and Sugar loaf variety deviated from the standard yellow colour more than Smooth cayenne and $\mathrm{MD}_{2}$ varieties. This was buttress by the high Total Soluble Solids in 10\% and 20\% dilutions of Sugar loaf. The OSPS was acidic. In bread, incorporating 5\% OSPS (w:w) of Sugar loaf recorded the highest percentage acceptability among the pineapple varieties. Interestingly, in the production of cakes with $15 \%, 20 \%$ and $30 \%$ OSPS, $\mathrm{MD}_{2}$ recorded the highest percentage overall acceptance. For bread and cake, there was varied significance $(P<0.05)$ of the sensory properties for appearance, colour, aroma, taste, texture, crust, mouthfeel and overall acceptance. Notably, cake and bread with incorporated OSPS of $15 \% \mathrm{MD}_{2}$ and $5 \%$ Sugar loaf was more acceptable.
\end{abstract}

Keywords: Physicochemical; Sensory; Proximate; Organic Side-Stream; Pineapple; Syrup

\section{Introduction}

Pineapple (Ananas sp.) belongs to the family Bromeliaceae which encompasses about 50 genera and 2000 species mostly epiphytic [1]. It is a tropical fruit native to Central and South America specifically southern Brazil and Paraguay where wild relatives occur [2]. The worldwide total pineapple production is between 16 to 19 million tons [2-4]. Pineapple mainly contains water, carbohydrates, sugars, vitamins A, C and beta carotene [5]. It contains low amounts of protein, fat, ash and fiber and antioxidants namely flavonoids in addition to citric and malic acids and moderate amounts of ascorbic acid [6]. Pineapple also helps several enzymes present in the body to produce energy as it contains magnesium and vitamin $\mathrm{B}_{1}$ which are essential for the normal functioning of some enzymes [7].

Pineapple has the enzyme complex protease (bromelain). Bromelain contains peroxidase, acid phosphatase, several protease inhibitors and organically bound calcium and have anti-inflammatory properties as

${ }^{*}$ Corresponding author. it blocks the formation of kinins which are responsible for inflammations [8]. Bromelain is used for relieving the pains, sprains, swelling, bruises, and arthritis and assist in diluting mucous and thus is beneficial for treating sinusitis, bronchitis, sore throat and tuberculosis [9]. Pineapples offer additional advantages for a whole utilization, in particular as a dietary fiber source. Among the qualities of the fiber is the texture, its length $(60 \mathrm{~cm})$, high water and dye holding capacity, high whiteness, brightness, resistance to salt and tension strength. The dietary fibre helps alleviate constipation as a indigestible portion of plant food that pushes through the digestive system, absorbs water and ease defecation and changes the nature of the gastrointestinal tract by changing how other nutrients and chemicals are absorbed $[10,11]$.

The consumption of pineapple is largely as canned pineapple slices, chunk and dice, juice, fruit salads, sugar syrup, alcohol, citric acid, chips and puree. It is also exported to other countries as fresh produce. Sixty percent of fresh pineapple is edible and average yield in processing ranges from $45 \%$ to $55 \%$ [7]. Processing residuals ranges between $45 \%$ to $65 \%$ an indication of serious organic-side streams disposal challenges, which causes en- 
vironmental pollution if not successfully utilized [12]. Pineapple peel is rich in cellulose, hemicelluloses and other carbohydrates. Ensilaging of pineapple peels produces methane as a biogas. Anaerobic digestion occurs and the digested slurry is used as animal, poultry and fish feeds or organic fertilizers [13]. In studies by Correia et al. [14], Rhizopus oligosporous was used to produce enhanced levels of free phenolics from pineapple residue in combination with soy flour as potential nitrogen source. Using Reverse Micellar Extraction (RME) technique, Hebbar et al. [6] extract and purify bromelain from pineapple wastes. De-juiced pineapple pulps, which are fruit fibers important for human health-including boosting satiety, slowing glucose absorption, and functioning as prebiotics fruit fibers often ends up being thrown away or used as animal feed. Deliza et al., [12] successfully incorporated de-juiced pineapple pulps fibers incorporated into human food as carriers for fruit flavours. As more pineapples are been produced and processed into various economic derivatives with the resultant $45 \%$ to $65 \%$ organic-side streams disposal challenges, the development of organic-side stream pineapple syrup (OSPS) for commercial use is another alternative utilization option which is limited in literature. This study seeks to develop pineapple organic side-steam syrup from dejuiced pineapple pulps, analysis its physicochemical and proximate properties and further conduct a sensory evaluation when incorporated in cake and bread products for commercial utilization in bakery and confectionary industries.

\section{Materials and Methods}

\subsection{Production of Organic Side-Steam Pineapple Syrup (OSPS)}

Freshly harvested physiological matured Smooth cayenne, Sugar loaf and $\mathrm{MD}_{2}$ pineapple varieties were obtained from local growers in the Central and Eastern regions in Ghana. The pineapples were sorted, decrowned, washed in $1 \%$ chlorine, subsequently washed in tap water, peeled, crushed and pulps collected at different times. The pineapple juice was pressed out using a manual press (Manual Presser, Furo Engineering, Lagos, Nigeria). The collected pulps were then washed in tap water at 100 $\mathrm{kg} / 50 \mathrm{~L}$, allowed to stand for $8-12 \mathrm{~h}$ covered and pressed after using a manual presser to obtain a seconddary juice. The secondary juice was boiled at $93^{\circ} \mathrm{C}$ $100^{\circ} \mathrm{C}$ for $10-14 \mathrm{~h}$ and stirred at every hour with continuous evaporation to obtain the organic side-stream pineapple syrup (OSPS) of Brix 70 - 78. The syrup was then packaged in sterilized glass bottles and stored on shelves at room temperature $\left(27^{\circ} \mathrm{C} \pm 3^{\circ} \mathrm{C}\right)$ until subsequent use.

\subsection{Determination of OSPS Water Activity, Total Soluble Solids and pH}

The water activity $\left(a_{w}\right)$ of the OSPS developed from the three varieties of pineapples was measured in triplicate each using a Rotronic HygroLab 2 (Rotronic AG, Bassersdrof, Germany). The equipment was calibrated using saturated salt solution of relative humidity of $70 \%$ $\left(0.75 \mathrm{a}_{\mathrm{w}}\right)$. The water activity was measured by transferring $8.0 \mathrm{~g}$ (Sartorius Portable, PT600, Sartorius GMBH, Gottingen, Germany) of OSPS into the chamber of the Rotronic HygroLab 2.

The Brix value of the OSPS was determined at the various dilution levels of $10 \%$ and $20 \%$ using a Grant Refractometer RB62 (HANNA Instruments, Germany). The refractometer was initially calibrated with distilled water and sucrose solutions before the determinations. The $\mathrm{pH}$ of the OSPS was measured using a 3330 Research $\mathrm{pH}$ Meter (Jenway Ltd., Essex, UK) by weighing $10.0 \mathrm{~g}$ and dissolved in $100 \mathrm{ml}$ of distilled water. The mixture was allowed to stand for $1 \mathrm{~h}$ and stirred before electrode was inserted for $\mathrm{pH}$ values.

\subsection{Colour Measurements of OSPS}

Colour measurements of the OSPS was conducted using a Minolta Chroma Meter (Model CR 310, Minolta Camera Co. Ltd., Japan), based on the $L^{*} a^{*} b^{*}$ colour system in duplicates. The Chroma meter was calibrated with a standard white background. $\left(L^{*}=97.63 a^{*}=-0.48 b^{*}=+\right.$ 2.12) as described in the Hunter Laboratory Manual [15].

\subsection{Determination of Proximate Composition of OSPS}

The proximate composition and chemical characteristics of OSPS was measured for moisture content, protein $(\mathrm{N} \times$ 6.25 ), crude fiber, fat, ash and carbohydrate. Total crude fiber was determined using the methodology described by Kirk and Sawyerr [16]. The moisture content, ash, fat protein, and crude fiber content of the OSPS was determined according to standard methods [17]. Caloric content (Energy) was determined using the Atwater Factor and in addition, vitamin $\mathrm{C}$ using 2,6-dichlorophenol indophenol [16]. Total carbohydrate was determined by the difference according to Kirk and Sawyerr [16].

\subsection{Sensory Evaluation}

Cake and bread preparations with OSPS were conducted in blends with wheat flour. The 15\% OSPS incorporated cake recipe consisted of soft wheat flour $(2.425 \mathrm{~kg})$, granulated sugar (400 g), margarine (450 g), baking powder $(8.4 \mathrm{~g})$, egg $(260 \mathrm{~g})$ and OSPS $(75 \mathrm{ml})$. The $20 \%$ 
OSPS incorporated caked had $3.233 \mathrm{~kg}$ soft wheat flour and $100 \mathrm{ml}$ OSPS. The $30 \%$ OSPS incorporated caked had $4.850 \mathrm{~kg}$ soft wheat flour and $150 \mathrm{ml}$ OSPS. The bread recipe consisted of strong wheat flour $(510 \mathrm{~g})$, granulated sugar ( $40 \mathrm{~g})$, margarine ( $100 \mathrm{~g})$, baker's yeast $(3.55 \mathrm{~g})$, warm diluted milk (500 mls), salt ( $2.5 \mathrm{~g})$ for $5 \%$ OSPS incorporated bread. Cake baking was done with modification on baking temperature [18].

Sensory evaluation of the OSPS developed from the three varieties of pineapple employed at $15 \%, 20 \%$ and $30 \%$ in cake and $5 \%$ in bread with wheat flour was conducted by twenty trained panelist using a 9-point Hedonic scale to assess attributes of appearance, colour, crispness, aroma, taste, texture, mouthfeel and overall acceptability. Control samples had no added OSPS. The sensory evaluation was conducted at the CSIR-FRI Nutrition and Socio-economic Division's Test Kitchen. An atmosphere of complete quietness and privacy was provided for each panelist. The sensory evaluation was conducted between 10:30 am and 11:30 am and samples were coded with 3-digit random numbers and a randomized complete block design was used in which the samples were randomly assigned to each panelist $[19,20]$. The 9-point Hedonic scale was rated as $9=$ like extremely, $8=$ like very much, $7=$ like moderately, $6=$ like slightly, $5=$ neither like nor dislike, $4=$ dislike slightly, $3=$ dislike moderately, 2 = dislike very much, $1=$ dislike extremely [21].

\subsection{Statistical Analysis}

The Statistical Analysis Systems version 9.1 software package was used to statistically analyzed the data obtained for all treatments. Significance of treatment means was tested at $P<0.05$ probability level using Duncan's New Multiple Range Test (DNMRT).

\section{Results and Discussion}

\subsection{Water Activity, Total Soluble Solids and pH Measurements of OSPS}

Water activity is very important for the shelf stability of foods. The microbial loads, shelf life, texture, aroma and smell of fruit syrups are affected by water activity. Food products with lower water activity show better stability and shelf-life. According to Beuchat [22] most products are safe if the water activity level was $0.7-0.9$. The OSPS prepared from $\mathrm{MD}_{2}$, sugar loaf and Smooth cayenne pineapple varieties showed varying significant differences $(P<0.05)$ in their total soluble solids and $\mathrm{pH}$ and not in the water activity (Table 1). The OSPS total soluble solids were in the ranges of $71.5-73.5$ Brix and $52.0-64.0$ Brix at $10 \%$ and $20 \%$ dilution, respectively (Table 1). The OSPS prepared from Sugar loaf recorded the highest total soluble solids and was statistically significantly different $(P<0.05)$ compared to $\mathrm{MD}_{2}$ and Smooth cayenne. The higher Brix recorded by Sugar loaf is an indication of high sugar molecules in OSPS, which is shown in their varying $\mathrm{pH}$ that differs statistically $(P<$ 0.05), indicating the acidic nature of the OSPS (Table 1). Studies on Ananas camosus showed similar results for pineapple core dietary fiber [23-24].

\subsection{Colour Changes of OSPS}

Colour changes of the OSPS measured for $L^{*}$ and $b^{*}$ were in the range of $35.24-37.87$ and $14.09-14.28$, respectively for $\mathrm{MD}_{2}$, Sugar loaf and Smooth cayenne (Figure 1). Colorimetry measurement of the OSPS for the three pineapple varieties was based on the Hunters system using $L^{*}, a^{*}, b^{*}$ values [25]. The colorimetry measurements for OSPS within the three varieties of pineapples were significantly different $(P<0.05)$ for $L^{*}, a^{*}$ and $b^{*}$. However, a more positive $a^{*}$ value was observed for $\mathrm{MD}_{2}$ representing the occurrence of browning, which statistically differed from Sugar loaf and Smooth cayenne. Colour is one of the most important attributes of food both for its aesthetic value and for quality judgment. Colour in fruits and vegetables is associated with the presences of polyphenoloxidase (PPO), which causes colour changes when it oxidises $O$-diphenols to $O$ quinones, which consequently polymerise and produce

Table 1. Water activity, Total Soluble Solids (Brix) at various dilutions and $\mathrm{pH}$ of OSPS from three varieties of pineapple.

\begin{tabular}{ccccc}
\hline Pineapple & Dilutions (\%) & \multicolumn{2}{c}{$\mathbf{p H}$} \\
\hline Variety & $\mathbf{1 0}$ & $\mathbf{2 0}$ & Water activity \\
\hline $\mathrm{MD}_{2}$ & $72.0 \pm 0.0 \mathrm{~b}$ & $55.0 \pm 0.0 \mathrm{~b}$ & $3.44 \pm 0.01 \mathrm{a}$ & $0.718 \pm 0.009 \mathrm{ab}$ \\
$\begin{array}{c}\text { Sugar loaf } \\
\text { Smooth } \\
\text { cayenne }\end{array}$ & $73.5 \pm 0.4 \mathrm{c}$ & $64.0 \pm 0.0 \mathrm{c}$ & $3.62 \pm 0.07 \mathrm{c}$ & $0.566 \pm 0.009 \mathrm{a}$ \\
\hline
\end{tabular}

Mean \pm standard error within each column followed by a different letters are significantly different at $(P<0.05)$.

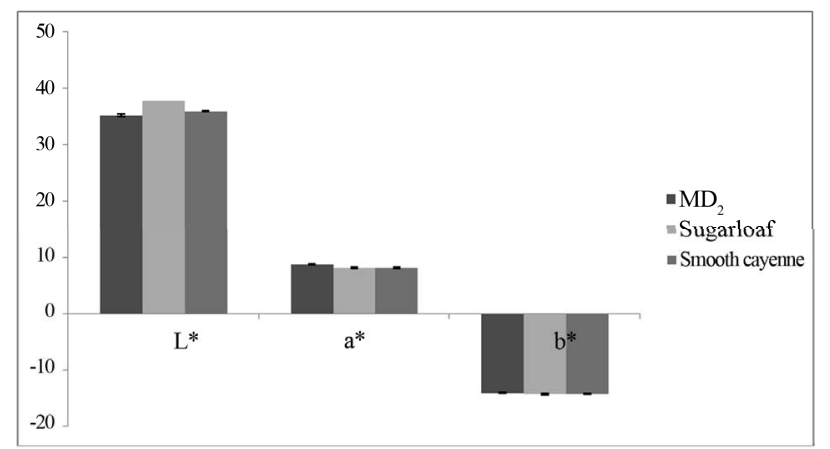

Figure 1. Colorimetric measurement of OSPS. 
brown pigments (melanin) [26]. However, pre-treatment process such as water blanching, stream blanching, osmodehydration and sulphating inhibit polyphenoloxi-dase (PPO) activities to cause browning [27-29].

\subsection{Proximate Analysis}

Table 2 shows the ranges of moisture content of the three varieties of OSPS between $29.67 \%-34.49 \%$. The moisture content was highest in OSPS prepared from Sugar loaf in agreement with its higher dilution in 10 and $20 \%$. Conditions such as differences in variety and maturity affect the moisture conditions of products. The content is affected by the presence of water, which is an important player in component mobility and in reaction rate is often measured as the water activity $\left(\mathrm{a}_{\mathrm{w}}\right)$ and moisture contents of foods [22]. The ash, fat and protein content were in the range of $1.32-1.92,0.73-0.85$ and $1.49-2.05 \mathrm{~g}$. The crude fiber yield of the OSPS were $0.51,0.47$ and $0.42 \mathrm{~g} / 100 \mathrm{~g}$ for Sugar loaf, Smooth cayenne and $\mathrm{MD}_{2}$, respectively, which are similar to waste pulp of pineapple (Ananas camosus) reported by Sreenath et al. [24]. Carbohydrate of the OSPS were 61.02, 65.74 and $61.92 \mathrm{~g} / 1000 \mathrm{~g}$ corresponding to energy of 253.15, 277.85 and $264.22 \mathrm{Kcal} / 100 \mathrm{~g}$ for Sugar loaf, Smooth cayenne and MD2, respectively, which were significantly different $(P<0.05)$ among the varieties (Table 2$)$. The amount of protein, fat and ash of OSPS varied significantly among the three pineapple varieties (Table 2). The proximate values of OSPS compared similarly with other fruits syrups and flours as reported for dehydrated soursop, guava and pineapple [30], pineapple core [23] and waste pulp pineapple [24]. Vitamin C which is important for wellness was significantly abundant in Sugar laof $(2.61 \mathrm{mg} / 100 \mathrm{~g})$ compared to Smooth cayenne $(2.52 \mathrm{mg} /$ $100 \mathrm{~g})$ and $\mathrm{MD} 2(2.25 \mathrm{mg} / 100 \mathrm{~g})$.

Table 2. Proximate parameter of OSPS developed from three pineapple varieties.

\begin{tabular}{cccc}
\hline Proximate & & \multicolumn{2}{c}{ Pineapple Variety } \\
\hline Parameter & Sugar Loaf & Smooth Cayenne & MD $_{2}$ \\
\hline Moisture & $34.49 \pm 0.08 \mathrm{c}$ & $29.67 \pm 0.30 \mathrm{a}$ & $33.27 \pm 0.30 \mathrm{~b}$ \\
Ash & $1.65 \pm 0.16 \mathrm{~b}$ & $1.32 \pm 0.02 \mathrm{a}$ & $1.92 \pm 0.04 \mathrm{c}$ \\
Fat & $0.85 \pm 0.11 \mathrm{a}$ & $0.74 \pm 0.12 \mathrm{a}$ & $0.73 \pm 0.06 \mathrm{a}$ \\
Protein & $1.49 \pm 0.0 \mathrm{a}$ & $2.05 \pm 0.02 \mathrm{c}$ & $1.74 \pm 0.03 \mathrm{~b}$ \\
Crude fiber & $0.51 \pm 0.07 \mathrm{a}$ & $0.47 \pm 0.16 \mathrm{a}$ & $0.42 \pm 0.04 \mathrm{a}$ \\
Carbohydrate & $61.02 \pm 0.13 \mathrm{a}$ & $65.74 \pm 0.58 \mathrm{~b}$ & $61.92 \pm 0.47 \mathrm{c}$ \\
Energy & $253.15 \pm 5.86 \mathrm{a}$ & $277.85 \pm 1.05 \mathrm{~b}$ & $264.22 \pm 6.49 \mathrm{c}$ \\
\hline
\end{tabular}

Mean \pm standard error within each row followed by a different letter are significantly different at $P<0.05$.

\subsection{Sensory Evaluation of OSPF}

Figures 2-5 show the sensory analysis conducted on OSPS in cakes and bread on attributes of appearance, colour, aroma, taste, texture, crust, mouth feel and overall acceptance. The mean scores of the control samples was adjudged best for all the sensory attributes except appearance and colour of $15 \%$ OSPS of $\mathrm{MD}_{2}$ incorporated in cakes (Figures 2-5). The OSPS incorporated in cake shows $\mathrm{MD}_{2}$ as the highest percentage overall acceptance in $15 \%, 20 \%$ and $30 \%$ incorporation, whereas in bread Sugar loaf had the highest percentage at $5 \%$

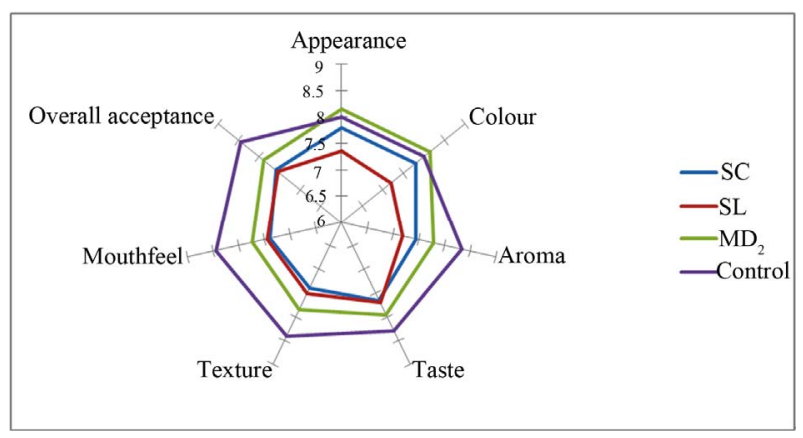

Figure 2. Sensory attributes of $\mathbf{1 5 \%}$ OSPS incorporated in cake.

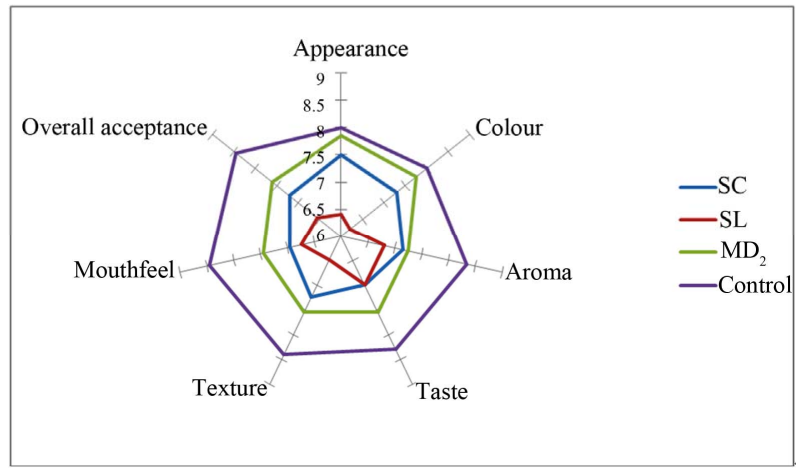

Figure 3. Sensory attributes of $\mathbf{2 0} \%$ OSPS incorporated in cake.

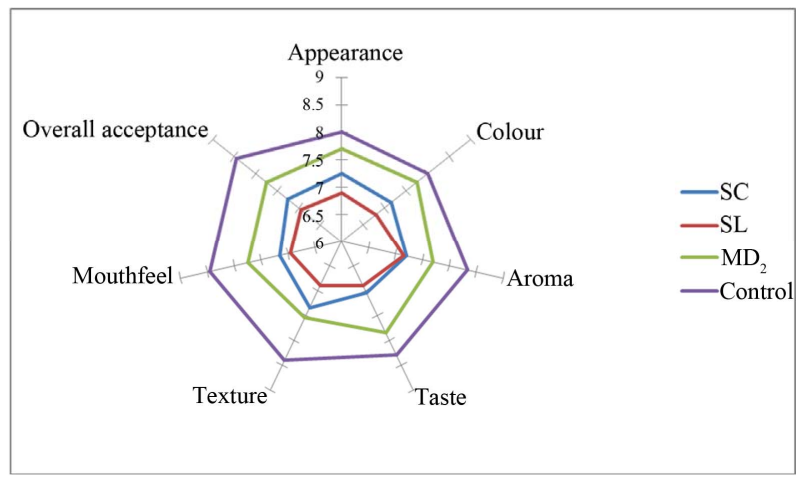

Figure 4. Sensory attributes of $30 \%$ OSPS incorporated in cake. 


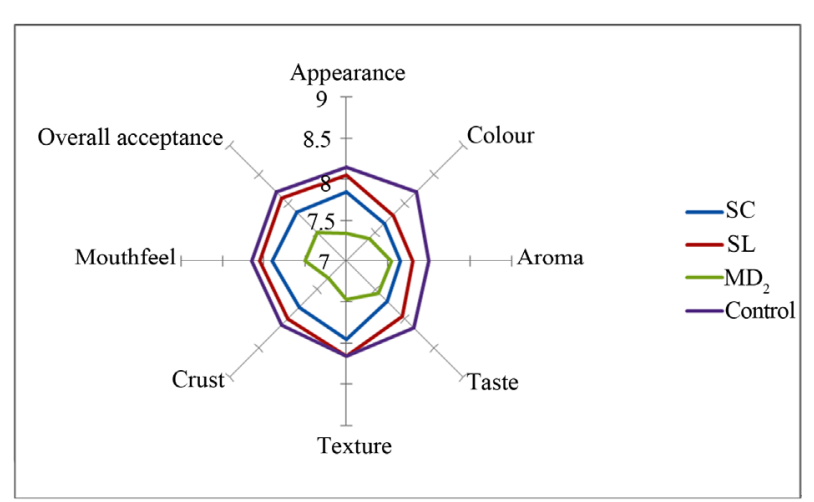

Figure 5. Sensory attributes of 5\% OSPS incorporated in bread.

incorporation. Ramirez and de Delahaye, [30] reported similar study and due to its hydration properties and flavor, pineapple flour was recommended in the preparation of crackers and as ingredients in desserts. Similar observations were reported for good sensory functions for pineapple core fiber incorporated in cake-type doughnuts, golden layer cake and beef burgers [23]. Notably, Sreenath et al., [24] reported that sensory quality evaluation for Ananas camosus pineapple flour incorporated in sponge cakes had similar acceptability to control sponge cakes, which is similar to that reported for cakes incurporated with OSPS in this study. In preparation of confectionary products the addition of OSPS depends on the nature of the confectionary product to be prepared. An important component of wheat flour in bakery is the protein of the gluten that plays a decisive role in dough formation, gas retention and the structure of the crumbs, which is lacking in the OSPS.

\section{Conclusion}

Development of organic side-stream pineapple syrup from pineapple pulp is feasible for $\mathrm{MD}_{2}$, Sugar loaf and Smooth cayenne varieties of pineapple. Physicochemical properties of the OSPS among the varieties varied significantly. The sensory attributes of cake with OSPS incorporated at $15 \%$ using $\mathrm{MD}_{2}$ variety was more acceptable than caked prepared using Smooth cayenne and Sugar loaf. However, OSPS incorporated in bread was more acceptable for 5\% Sugar loaf among the varieties. The acceptable limits of $15 \% \mathrm{MD}_{2}$ and $5 \%$ Sugar loaf for cake and bread, respectively are recommended for bakery. Further development must consider the shelf-life studies of cake and bread with OSPS incorporated for the three varieties of pineapple.

\section{Acknowledgements}

The TNO-Netherlands sponsorship for this study is gratefully acknowledge.

\section{REFERENCES}

[1] D. P. Bartholomew and E. B. Maleieux, "Pineapple," 2nd Edition, CRC Press Incorporated, Boca Raton, 1994, pp. 42-66.

[2] F. A. N. Fernandes Jr., F. E. Linhares and S. Rodrigues, "Ultrasound as Pre-Treatment for Drying of Pineapple," Ultrasonic Sonochemistry, Vol. 15, No. 6, 2008, pp. 10491054. doi:10.1016/j.ultsonch.2008.03.009

[3] L. M. de Carvalho Jaeger, I. M. de Castro and C. A. B. da Silva, "A Study of Retention of Sugars in the Process of Clarification of Pineapple Juice (Ananas cosmosus, L. Merril) by Micro- and Ultra-Filtration," Journal of Food Engineering, Vol. 87, No. 4, 2008, pp. 447-454. doi:10.1016/j.jfoodeng.2007.12.015

[4] FAO, "Production Year Book 2009," Food and Agriculture Organization, Rome, 2009.

[5] J. L. Slavin, "Position of the American Dietetic Association: Health Implications of Dietary Fiber," Journal of the American Dietetic Association, Vol. 108, No. 10, 2008, p. 1716. doi:10.1016/j.jada.2008.08.007

[6] H. U. Hebbar, B. Sumana and K. S. M. S. Raghavarao, "Use of Reverse Micellar Systems for the Extraction and Purification of Bromelain from Pineapple Wastes," Journal of Bioresources Technology, Vol. 99, No. 11, 2008, pp. 4896-4902. doi:10.1016/j.biortech.2007.09.038

[7] J. A. Samson, "Tropical Fruits," Longman Incorporated Publishers, New York, 1986, pp. 44-56.

[8] B. N. Tochi, Z. Wang, S.-Y. Xu and W. Zhang, "Therapeutic Application of Pineapple Protease (Bromelain): A Review," Pakistan Journal of Nutrition, Vol. 7, No. 4, 2008, pp. 513-520. doi:10.3923/pjn.2008.513.520

[9] I. MacDonald and J. Low, "Tropical Field Crop," 2nd Edition, Evans Brothers Limited, London, 1996, p. 58.

[10] M. Eastwood and D. Kritchevsky, "Dietary Fiber: How Did We Get Where We Are," Journal of Food Sciences, Vol. 25, 2005, pp. 1-8.

[11] National Academy of Sciences, "Dietary Reference Intakes," Journal of Food and Nutrition, Vol. 43, 2010, pp. 473-512.

[12] R. Deliza, A. Rosenthal, F. B. D. Abadio, C. H. O. Silva and C. Castillo, "Utilization of Pineapple Waste from Juice Processing Industries: Benefits Perceived by Consumers," Journal of Food Engineering, Vol. 67, No. 1-2, 2005. pp. 241-246. doi:10.1016/j.jfoodeng.2004.05.068

[13] D. S. Rani and K. Nand, "Ensilage of Pineapple Processing Waste for Methane Generation," Journal of Waste Management, Vol. 24, No. 5, 2004, pp. 523-528. doi:10.1016/j.wasman.2003.10.010

[14] R. T. P. Correia, P. McCue, M. M. A. Magalhaes, G. R. Macedo and K. Shetty, "Production of Phenolic Antioxidants by the Solid-State Bioconversion of Pineapple Waste Mixed with Soy Flour Using Rhizopus oligosporus," Process Biochemistry Journal, Vol. 39, 2004, pp. 2167-4902. doi:10.1016/j.procbio.2003.11.034

[15] Hunter Laboratory Manual, "Hunter Associate Laboratory Universal Software, Version 3.8. ISO 9001 Certified," 
Reston, 2001.

[16] R. S. Kirk and R. Sawyerr, "Pearson's Composition and Analysis of Foods," 9th Edition, Longman Singapore Publishers (Pte) Ltd., 1990, p. 578.

[17] AOAC, "Official Methods of Analysis," 17th Edition, Association of Official Analytical Chemist International, Washington DC, 2000.

[18] A. I. Ihekoronye and P. O. Ngoddy, "Integrated Food Science and Technologies for the Tropics," Macmillian Publishers Ltd., London, 1985, pp. 182-184.

[19] R. Rampersad, N. Badrie and E. Comissiong, "Physiochemical and Sensory Characteristics of Flavored Snacks from Extruded Cassava/Pigeon Pea Flour," Journal of Food Science, Vol. 68, No. 1, 2003, pp. 363-367. doi:10.1111/j.1365-2621.2003.tb14166.x

[20] S. Hooda and S. Jood, "Organoleptic and Nutritional Evaluation of Wheat Biscuits Supplemented with Untreated and Treated Fenugreek Flour," Food Chemistry, Vol. 90, No. 3, 2005, pp. 427-435. doi:10.1016/j.foodchem.2004.05.006

[21] H. T. Lawless and H. Heymann, "Sensory Evaluation of Food: Principles and Practices," Chapman and Hall, New York, 1998, p. 827.

[22] L. Beuchat, "Water Activity and Microbial Stability," Center for Food Safety and Department of Food Science and Technology, University of Georgia, Athens, 1997.

[23] T. Prakongpan, A. Nitithamyong and P. Luangpituksa, "Extraction and Application of Dietary Fiber and Cellulose from Pineapple Cores," Journal of Food Science, Vol. 67, No. 4, 2002, pp. 1308-1313. doi:10.1111/j.1365-2621.2002.tb10279.x

[24] H. K. Sreenath, K. R. Sudarshanakrishna, N. N. Prasad and K. Santhanam, "Characteristics of Some Fiber Incorporated Cake Preparations and Their Dietary Fiber Content," Starch-Starke, Vol. 48, No. 2, 1996, pp. 72-76. doi:10.1002/star.19960480208

[25] C. M. Brien, D. Chapman, D. P. Neville, M. K. Keogh and E. K. Arendt, "Effect of Varying the Microencapsulation Process on the Functionality of Hydrogenated Vegetable Fat in Shortdough Biscuits," Food Research International, Vol. 36, No. 3, 2003, pp. 215-221. doi:10.1016/S0963-9969(02)00139-4

[26] M. A. Mayer and E. Harel, "Review: Polyphenoloxidases in Plants," Phytochemistry, Vol. 18, No. 2, 1979, pp. 193215. doi:10.1016/0031-9422(79)80057-6

[27] H. E. Moline, J. G. Buta and I. M. Newman, "Prevention of Browning of Banana Slices Using Natural Products and Their Derivatives," Journal of Food Quality, Vol. 22, No. 5, 1999, pp. 499-511. doi:10.1111/j.1745-4557.1999.tb00181.x

[28] J. G. Buta and H. E. Moline, "Prevention of Browning of Potato Slices Using Polyphenoloxidase Inhibitors and Organic Acids," Journal of Food Quality, Vol. 24, No. 4, 2000, pp. 271-282. doi:10.1111/j.1745-4557.2001.tb00608.x

[29] G. A. Gonzalez-Aguilar, C. Y. Wang and J. G. Buta, "Inhibition of Browning and Decay of Fresh Cut Radish by Natural Compounds and Their Derivatives," Lebensmittel-Wissenschaft und-Technologie, Vol. 34, 2001, pp. 324 328.

[30] A. Ramirez and E. P. de Delahaye, "Functional Properties of Starches with High Dietetic Fiber Content Obtained from Pineapple, Guava and Soursop," Interciencia, Vol. 34, No. 4, 2009, pp. 293-298. 